\title{
СОВЕРШЕНСТВОВАНИЕ СИСТЕМЫ УПРАВЛЕНЧЕСКОГО УЧЕТА НА БАЗЕ СОВРЕМЕННЫХ ИНФОРМАЦИОННЫХ ТЕХНОЛОГИЙ НА ПРИМЕРЕ РЫНКА АВТОМОБИЛЬНЫХ ГРУЗОПЕРЕВОЗОК
}

\author{
(c) 2021 Савин А. A. \\ кандидат экономических наук, профессор Департамента аудита и корпоративной отчетности \\ Финансовый университет при Правительстве Российской Федерации, Россия, Москва \\ E-mail: aasavin@fa.ru
}

Состояние мировой транспортной системы меняется, так как ко всем видам транспорта в условиях глобализации и развития международных связей предъявляются всё новые требования. Предъявляются особые требования к скорости и своевременности доставки грузов. Развивается сеть складских и распределительных систем. Отсюда и возникает потребность в совершенствовании системы управленческого учета на базе современных информационных технологий.

Ключевые слова: учет, анализ, аудит, налогообложение, управленческий учет, транспортная система

По результатам анализа сфер экономики России компании Ernst \& Young транспортная отрасль играет важную роль в российской экономике, её доля в структуре валовой добавленной стоимости достигает 7\%. Грузооборот российского транспорта показывает стабильный рост на протяжении последних нескольких лет. В 2018 году грузооборот российского транспорта по Российской Федерации увеличился на $2,8 \%$, а объем перевезенных грузов - на 2,4\%. В 2019 году рост продолжился, в 2020 года изза COVID-кризиса произошло падение. Также отдельно выделяются сборные перевозки, как сложное, но перспективное и прибыльное направление.

Сборные перевозки - это перевозки мелкогабаритных грузов различных заказчиков в одном направлении на одном транспортном средстве. Для осуществления транспортировки сборных грузов необходимо учитывать множество факторов, влияющих на результаты работы транспортной компании. Работа с большим объёмом данных для принятия управленческих и оперативных решений является неотъемлемой частью этого вида перевозок, который невозможно представить без использования современных информационных технологий.

Одним из главных трендов рынка автомобильных грузоперевозок является цифровизация и внедрение новых технологий. При высокой конкуренции на рынке и растущим объёмом предоставляемых услуг автоматизация многих процессов является необходимым требованием для развития компании. Автоматизация бизнеспроцессов позволяет:

- уменьшить риски «человеческого фактоpa»;

- освободить персонал от рутинной работы;

- быстро получить необходимые отчёты;

- вводить и обеспечивать сохранность большого объёма информации;

- эффективно поддерживать оперативную деятельность предприятия;

- повысить качество обслуживания заказчиков.

Однако у каждой компании своя специфика работы и многим не подходят общие инструменты ведения бизнеса в сфере логистики.

Немаловажным критерием выбора ERP - системы компанией, связанной с грузовыми перевозками, вполне может являться наличие готового решения задачи правильного распределение машин на отгрузку в регионы с основного склада, потому что для принятия решения об очерёдности постановки необходимо учитывать большое количество постоянно изменяющихся параметров каждой перевозки, количество которых во время отгрузки варьируется от шестидесяти до девяноста.

Разработкой ERP - систем в сфере грузоперевозок занимается ни одна IT компания, но уже привычным для российского рынка стало решение об автоматизации логистических процессов на основе системы 1C: Предприятие Сборные Грузы. Чем хороша эта система, так это разработанными инструментами автоматизации пла- 
нирования постановки на загрузку автомашин на складе консолидации.

Автоматизация логистических процессов включает в себя:

- Учёт прихода груза на склад консолидации;

- Оприходование груза на складе консолидации;

- Учёт приезда транспортных средств на загрузку;

- Планинг времени постановки машин на загрузку;

- Разработка универсальной формулы для расчёта крайнего возможного времени отъезда машин со склада в пункт доставки;
- Формирование маршрутов;

- Загрузка машин сборным грузом.

Результатом автоматизации бизнеспроцессов должна стать чёткая система получения информации, которая будет использоваться для принятия оперативных решений. Также система позволит получать необходимую информацию в виде отчётов для принятия управленческих решений.

Правильно структурированная информация даёт возможность оценить каждый этап предоставляемой услуги (от приёма заказа от клиента до оповещения клиента о сдаче товара на пункте доставки), проанализировать результаты и принять необходимые управленческие решения.

\section{Библиографический список}

1. Власов В.М., ЕфименкоД.Б., Богумил В.Н. Информационные технологии на автомобильном транспорте. Учебник.-М.: Academia, 2014.-256 с.

2. Миротин Л.Б., Боков В.В. Современный инструментарий логистического управления: Учебник для вузов М.: Издательство «Экзамен», 2015.-174 с.

3. Букреев А.Ю. Информационная система управления движением продукции на складах / Программные продукты и системы.-2010.- N 1.-C. 101-103.

4. Internet resource: Transportation as a science URL: www.klsair.com/information_technology.html

5. Интернет ресурс: Автоматизация склада: как автоматизировать работы, процессы, операции, учёт на предприятии URL: www.cleverence.ru/articles/auto-busines/avtomatizatsiya-sklada-kak-avtomatizirovat-rabotyprotsessy-operatsii-uchyet-na-predpriyatii.html

6. Семчугова Е.Ю., Цыплаков В.Ю. Размещение инфраструктуры двухэтапной транспортировки в городских условиях с использованием МАИС-методов / Инженерный вестник Дона, 2017, № 3 URL: www.ivdon.ru/ru/ magazine/archive/n4p1y2012/1083 